\title{
NOTAS SOBRE A “TUTELA INDÍGENA” NO BRASIL (LEGAL E REAL), COM TOQUES DE PARTICULARIDADES DO SUL DE MATO GROSSO DO SUL
}

\author{
NOTES ON “INDIGENOUS GUARDIANSHIP” IN BRAZIL (LEGAL AND \\ REAL), WITH SOME PARTICULARITIES OF THE SOUTHERN MATO \\ GROSSO DO SUL
}

\author{
Simone Becker \\ Universidade Federal da Grande Dourados (UFGD) - (Dourados, MS, Brasil) \\ Taís Cássia Peçanha Rocha \\ Universidade Federal da Grande Dourados (UFGD) - (Dourados, MS, Brasil)
}

Recebimento: 27 nov. 2016

Aceitação: 31 jul. 2017

Como citar este artigo / How to cite this article (informe a data atual de acesso / inform the current date of access):

BECKER, Simone; ROCHA, Taís Cássia Peçanha. Notas sobre a "tutela indígena” no Brasil (legal e real), com toques de particularidades do sul de Mato Grosso do Sul. Revista da Faculdade de Direito UFPR, Curitiba, PR, Brasil, v. 62, n. 2, p. 73 - 105, maio/ago. 2017. ISSN 2236-7284. Disponível em: <http://revistas.ufpr.br/direito/article/view/49443>. Acesso em: 28 ago. 2017. DOI: http://dx.doi.org/10.5380/rfdufpr.v62i2.49443.

\section{RESUMO}

Neste artigo será analisada a tutela indigenista, observando o seu rastro histórico e a remanescência de sua ideia nas relações entre indígenas e instituições civis e governamentais. Verificar-se-á quando a tutela passa a caracterizar o racismo institucional, na medida em que ela representa entrave ao indígena no alcance de direitos, ainda que a atual Constituição Federal a tenha extinguido, reconhecendo a capacidade civil plena do indígena brasileiro. Suscitam-se indagações sugestivas, tanto dos “indigenismos” em nosso País quanto da capacidade civil do “índio”, além daquelas referentes ao órgão indigenista, a Fundação Nacional do Índio (Funai). Demonstrar-se-á que o preconceito étnico e o racismo institucional caminham lado a lado, o segundo em decorrência do primeiro, num processo de subtração da cidadania indígena. Para tanto, analisar-se-á fato ocorrido no âmbito da Coordenação Regional da Funai em Dourados/MS, em comunidade indígena por ela atendida, referente à emissão de Declaração de Aptidão ao Programa Nacional de Fortalecimento da Agricultura Familiar (Pronaf). Sugere-se que a aplicação da tutela pode ser um fator descaracterizante do protagonismo indígena, que o relega aos caminhos burocráticos circulares de negação de responsabilidade, impedindo-o de alcançar a cidadania plena.

\section{PALAVRAS-CHAVE}

Integracionismo. Protagonismo indígena. Racismo institucional. Tutela.

\begin{abstract}
This article aims to analyze the indigenous people guardianship, observing its historical traces and the remanence of its idea in the relationship between indigenous people and civil and governmental institutions. It will be checked how this relationship starts to characterize an institutional racism, with
\end{abstract}


the institute acting as a hindrance to the indigenous people seeking their rights, even though the current Federal Constitution had extinguished the indigenous guardianship, recognizing the full civil capacity of the Brazilian indigenous people. There are also suggestive inquiries, both from the "indigenisms" in our country and the civil capacity of "indigenous", as well as those relative to the local indigenist organ, the National Foundation of the Indigenous (Funai). It will be demonstrated that ethnic prejudice and institutional racism go together, the second as a consequence of the first, in a process of subtraction of indigenous citizenship. For such demonstration, it will be analyzed an experience from the Regional Coordination of Funai, at an indigenous community that is served by this institution in the city of Dourados/MS, about the issuance of a Declaration of Aptitude to the National Program to Strengthen Family Agriculture (Pronaf). It is suggested that the indigenous guardianship can decharacterize indigenous protagonism, relegating indigenous people to the circular bureaucratic ways of denying the responsibility that prevents them from reaching full citizenship.

\section{KEYWORDS}

Integracionism. Indigenous protagonism. Institucional racism. Indigenous guardianship.

\section{INTRODUÇÃO}

Ao iniciarmos ${ }^{1}$ o resgate da tutela indigenista no sentido mais plural do termo, necessário se faz empreendermos uma análise da sua “origem”, tomando-a na forma da fôrma menos singularizada porque mais plural possível. Inicialmente, podemos entender a tutela indigenista como uma espécie de poder exercido pelo Estado sobre as populações indígenas, capaz de em tese calá-las². Michel Foucault, em Microfísica do Poder, trabalho publicado no Brasil pela primeira vez em 1979 (FOUCAULT, 2015), retira o poder da esfera macrossociológica vinculada à política e o traduz na esfera da capilaridade cotidiana - microssociológica -, demonstrando seu exercício em uma gama de relações pessoais, sem deixar, contudo, de reconhecer que o interesse hegemônico, de diferentes grupos sociais, faz nascer o poder em situações mais generalizadas/estruturais.

Eis que, buscando realizar um estudo sobre as formas de individualização e assujeitamento que cingem as práticas do governo, Foucault contraria as ditas origens economicistas e jusnaturalistas do poder, para representá-lo mediante perguntas sobre o seu exercício: seus mecanismos, efeitos, relações e técnicas; em suma, o como do exercício do poder (LIMA, 2012, p. 789).

\footnotetext{
${ }^{1}$ Usa-se ao longo do artigo o recurso da primeira pessoa do plural, ante o fato de essa pesquisa se dar na interface com a antropologia. Nesta, cuja metodologia clássica é a etnografia, torna-se condição, sem a qual se desconsideraria a interação de subjetividades no trabalho de campo (da "participação observante” ao invés da imparcial “observação participante”), mesmo que ele se dê a partir de documentos. Então, a escrita em primeira pessoa do singular ou do plural é corriqueira, porque consequência do próprio métier antropológico. Aliás, a "autoridade etnográfica” do "estar lá” em meio à "participação observante” contribui para a própria construção do que analisamos, reforçando a inexistência de um sujeito a priori e descolado da ação ou da performatividade. Para esclarecimentos adicionais, sugere-se a consulta, por exemplo, ao artigo de Stephen Tyler, na coletânea sobre a discussão da etnografia pós-moderna (1991).

${ }^{2}$ Em tese porque o que há, quiçá, seja a não escuta, e não necessariamente o ato de calar os chamados "tutelados”, uma vez que historicamente os indígenas sempre produziram re-existências. Veremos, mesmo que en passant, o quanto os indígenas brasileiros produzem re-existências e resistências ao longo de nossa produção nacional e histórica.
} 
Foucault afirma que “o poder não se dá, não se troca nem se retoma, mas se exerce, só existe em ação, como também da afirmação que o poder não é principalmente manutenção e reprodução das relações econômicas, mas acima de tudo uma relação de força” (FOUCAULT, 2015, p. 274). Mediante tal afirmativa, e em decorrência desta, Foucault nos remete a dois esquemas de análise do poder: aquele oriundo do sistema contrato-opressão, e aquele denominado por ele de dominaçãorepressão ou guerra-repressão, pelos quais se desenvolveria uma oposição entre a luta e a submissão.

Antônio Carlos de Souza Lima analisa as proposições realizadas na mencionada obra e conta-nos que três importantes implicações para a construção da ideia de poder tutelar podem ser retiradas como conclusão:

A primeira [...] é a de que as relações de poder atuais remontam historicamente à guerra, $\mathbf{e}$ que o poder político, ao se fazer a paz, reatualiza a guerra de diferentes modos. A segunda constatação é a de que consequentemente se deve interpretar as lutas políticas como formas de continuidade e de deslocamento da guerra. Por fim, $[\ldots]$ a guerra deve ser o último juiz do conflito. (LIMA, 2012, p. 790, grifo nosso)

O autor sugere, portanto, que não devemos interpretar a guerra, tão somente, como forma de “destruição e catástrofe”, mas ampliar sua mecânica para abranger a construção de novos sistemas de antagonismos e alianças ${ }^{3}$.

A guerra, aqui, é analisada como mecanismo de poder constituído por meio das relações sociais por ela engendradas. A conquista, ou guerra da conquista, conforme termos de Antônio Carlos de Souza Lima, pode ser entendida como sistema de relações de força entre conquistador e conquistado, pois pela conquista possibilita-se descontruir o conquistado, permitindo-se reavaliar os seus significados mediante o paradigma do conquistador que o traz para o seu "lugar comum" cultural.

O autor menciona, ainda, que a conquista se fundamenta e se opera mediante o "reconhecimento da alteridade”, da qual o conquistador se utiliza para "instrumentalmente prever os passos e manipular o inimigo com eficácia em face dos objetivos dos conquistadores” (LIMA, 2012, p. 792). Cabe ressalvar que manipular envolve também ser manipulado por quem se acha (também) manipulador/dominador, como poderoso-potente.

Assim, ao falarmos de indigenismo e de como a colonização se impôs aos denominados “índios”4, não sem resistências ou re-existências, observa-se que o século XIX foi de suma

\footnotetext{
${ }^{3}$ Pierre Clastres, ampliando as noções levistraussianas, esmiúça o quanto o social e seus enlaces re-elacionais se pautam também por meio da guerra/dos conflitos/dos em-bates, e não apenas pela aliança/troca que engendram sentidos múltiplos às mulheres, bens, crianças, entre outros signos/significantes/simbolismos.

${ }^{4}$ Lembremos que é o Estado quem impõe aos originários das terras brasilis a chancela de índios, por equívoco de confundir as Índias com as Américas, onde aportaram. De qualquer forma, ao aderirem por protagonismo à identidade de
} 
importância tanto para o cenário nacional quanto para o da região que é o cenário de nosso estudo de caso, atual Mato Grosso do Sul, antigo Mato Grosso - a divisão do Estado ocorreu em 1977. Por quê? Porque é o período a partir do qual o positivismo se introduz e se capilariza sob os ditames lombrosianos, que, dentre os slogans, reproduz no corpo e por meio dele. É a partir de diferenças impostas pelo/no corpo que se instituem e se re-iteram ${ }^{5}$ as assimetrias sociais. No início da década de vinte do século dezenove, tais ditames positivistas são espraiados nos currículos das formações de médicos e bacharéis em direito, considerando que é a partir de meados da década de 1820 que são criadas as duas escolas de medicina e de direito, respectivamente, de um lado na Bahia e no Rio de Janeiro, e de outro, no Recife e em São Paulo. Aliás, como magistralmente analisa Lilia M. Schwarcz, em O Espetáculo das Raças (1993), mostrando como as influências ainda persistem6.

A tutela indigenista, então, apresenta uma de suas principais faces, a “tutela-representação”, mediante a qual o Estado se encobre do dever de “civilizar” o indígena, tornando-o um ser interessantemente útil à nação, mediante o paradigma do conquistador: de horda selvagem ao sertanejo produtivo. De qualquer forma, lembremos que essa fôrma na qual se assentavam os indígenas não era uma única forma de padronizá-l@s. Entre os “mansos” e os “bravos” ou indomáveis, as medidas estatais oscilavam, mas não sem convergirem para o projeto de integração nacional e de aculturação.

Em síntese, é sob e sobre a efervescência do século XIX - com todas as suas particularidades já anunciadas por nós, que "instituía-se uma nova forma política e social de se lidar com os indígenas, forma essa permeada de novos preceitos ideológicos, oriundos das teorias positivistas e darwinistas, bases epistemológicas também para as novas políticas indigenistas” (SANT’ANA, 2010, p. 90-91).

Seguindo a ótica da época sobre a transitoriedade da identidade indígena, o Código Civil de 1916 (CC/16) trouxe em seu bojo a possibilidade de o indígena se “adaptar progressivamente” mediante um sistema tutelar que promovesse sua incorporação à vida civil comum. Antes, porém, é

\footnotetext{
indígenas, não esqueçamos os movimentos que adiante chamaremos de esquizofrênicos por parte da perversidade estatal. Para esclarecimentos adicionais, sugerimos a visualização de artigo (disponível na internet) advindo de aula pública ("Os Involuntários da Pátria”) realizada por Eduardo Viveiros de Castro (2016b), no Rio de Janeiro, em plena Cinelândia, aos vinte dias do mês de abril de 2016.

${ }^{5}$ Escandimos algumas palavras propositadamente, a fim de que as pessoas leitoras possam se ater às possíveis e diferentes composições de um mesmo termo - movimento que não se confunde com a etimologia. Nesse caso, reiteração ou reiteração é a particularidade que nos institui como sujeitos a partir da ação repetida. Algo tomado, a nosso ver, por Michel Foucault, como convergindo para as próprias noções de discurso.

${ }^{6}$ Em matéria de capa do jornal de maior circulação em Curitiba - a Gazeta do Povo - de meados de novembro de 2016, a ode à tese do "criminoso nato", parece estampar-se com o retorno de banca de comprovação de negritude (ou não) na UFPR para os ingressantes cotistas. A ênfase da manchete intitulada "UFPR retoma banca para avaliar os selecionados por cotas sociais” é a de que a análise levará em consideração “exclusivamente o fenótipo”. Para a questão de como (não) se condena por racismo no Brasil, sugerimos a leitura de artigo de Simone Becker e Déborah G. Oliveira (2013).
} 
com a lei de Terras, de 1850, que as ações institucionais estatais se pautarão em meio aos rumos do projeto colonialista que (re)produz agenciamentos de outrora, mas que agora são intensificados com a domesticação de muitos indígenas não dizimados, junto às grades das reservas. Dentre elas, a entrega de muitas terras de posse dos indígenas e por eles ocupadas (desde "sempre”) como sendo parte do projeto de colonização dos rincões e sertões. Mas não apenas dos rincões e sertões, como considerado o centro-oeste (VIVEIROS DE CASTRO, 2016a; 2016b): “[...] o governo passou a declarar como devolutas inúmeros territórios e aldeamentos indígenas, grande parte deles sendo declarados como ‘terras de mestiços’ e não ‘terras de índios’” (SANT’ANA, 2010, p. 91).

Conta-nos Darcy Ribeiro que “Até a promulgação do Código Civil Brasileiro, era o índio identificado às pessoas completamente incapazes e sujeito à tutela dos juízes de órfãos” (RIBEIRO, 1996, p. 225).

A ressignificação da capacidade civil do indígena, trazida pelo Código Civil de 1916 e também pela Lei n 5.484 de 1928, fez com que este se submetesse à tutela direta do Estado, cabendo ao Serviço de Proteção ao Índio (SPI) executá-la. Há na mencionada lei, ainda, a previsão de que o indígena poderia “emancipar-se”, alcançando a capacidade de exercício das prerrogativas do cidadão comum, dependendo apenas de seu engajamento social mediante os parâmetros da cultura "branca”.

Ironias à parte, para mensurar este engajamento e para auxiliar esta transformação cultural recheada de ressignificações, o SPI (datado de 1910 como as primeiras reservas) desenvolveu práticas que até os dias de hoje repercutem no trato interinstitucional empreendido pela e para a Fundação Nacional do Índio (Funai), órgão que substituiu o SPI no ano de 1967, numa tentativa de perpetuarse a ideologia da tutela, mesmo após a mudança de parâmetros trazida pela Constituição Federal de 1988 (CF/88) e pela Convenção 169 da Organização Internacional do Trabalho (OIT). Uma tentativa, sobretudo se não nos ativermos às agências dos movimentos indígenas que emergiram com força na década de 1970, como ao longo do artigo esboçaremos. Algo absolutamente invisibilizado e resguardado sob o guarda-chuva da categoria tutela. Essa, por sua vez, não é significada da maneira mais plural possível, visto que perceber o protagonismo dos indígenas caminha de mãos dadas com menos vitimização por nós escorregada aos indígenas. O Código Civil de 1916 foi elaborado por Clóvis Beviláqua, e em seu projeto inicial não houve menção aos direitos dos indígenas, entendendo, o autor do Código, que os índios teriam forma própria de organização social e de instituições jurídicas, sendo necessário um encontro entre o universo jurídico estatal e o indígena, defendendo, para tanto, a criação de uma lei especial para o tratamento das obrigações estatais para com estes povos (MEYER, 2014, p. 83). 
Contudo, mediante proposta trazida pelo Senado, a temática indígena acabou por figurar na pauta do Código Civil, quando Moniz Freire propôs a sujeição das populações indígenas ao regime tutelar, enquanto estas se encontrassem em estágio de adaptação, com "capacidade relativa”7 (BRASIL, 1916).

Cinquenta e sete anos depois, a Lei ${ }^{0}$ 6.001, de 19 de dezembro de 1973, conhecida como Estatuto do Índio, foi inserida no ordenamento jurídico de nosso País, dando uma nova regulação à situação jurídica desses povos, nada distante do projeto colonizador da integração. É na década de setenta do século vinte que fluxos de contradições nietzschianos jogam cores em nossa (re)produção enquanto brasileirxs ${ }^{8}$. De um lado, tornam-se visíveis as demandas e manifestações dos indígenas e seus movimentos com as dezenas de assembleias Brasil adentro; de outro lado, medidas a reboque do Estatuto do Índio. Lembremos que estivemos imersos, de 1964 a 1985 (para fins de calendário judaico-cristão), em um regime totalitário de gerir as relações de ordem pública e privadas - vulgo ditadura militar - que parece não ter findado ${ }^{9}$. É neste entremeio, final da década de 1960 e meados da de 1980, que, nas bordas da estrutura e de dentro dela, emergem os protagonismos indígenas. Com os índios - que por nós "brancos cidadãos” assim foram nomeados impositivamente - gestando as (suas) políticas indígenas cada vez mais, apesar das poucas leis que os visibiliza(ra)m efetuarem o movimento esquizofrênico de os desindianizarem. Isto porque foi o próprio Estado que os indianizou e, paulatinamente, com genocídios declarados contras as sociedades indígenas, desindianiza-os (SAFATLE, 2016; VIVEIROS DE CASTRO, 2016a; 2016b).

Com o Estatuto do Índio pretendia-se, e ainda se pretende (BECKER; SOUZA; OLIVEIRA, 2013), efetivar duas importantes tarefas, no contexto ideológico aflorado à época: a de "preservar a cultura das comunidades indígenas e integrá-los progressiva e harmoniosamente, à comunhão nacional” (MEYER, 2014, p. 91). Dessa forma, manteve-se o sistema tutelar aos indígenas que ainda não haviam sido reconhecidos como integrados à comunhão nacional. Uma visão tutelar de representação restrita e engessada, porque ligada à noção e à ilusão de que os indígenas não têm fala

\footnotetext{
7 “Essa proposta, apesar de alterada, foi incluída na promulgação da Lei n 3.071, de 01 de janeiro de 1916 - o Código Civil [...]. Sob a determinação de 'silvícolas', os indígenas foram incluídos entre os 'incapazes, relativamente a certos atos, ou à maneira de os exercer' [...], juntamente com os pródigos e os jovens entre 16 a 21 anos [...] (MEYER, 2014, p. 83, grifo do autor).

${ }^{8}$ Considerando a misoginia e os etnocentrismos que se espraiaram no CC/16, inspirados nas costuras dos problemas na categoria gênero tecidas por Judith Butler (2003), grafamos "brasileiros” com “ $x$ ”, ao invés da forma como as normas da língua portuguesa determinam. Busca-se destacar o quanto o masculino tende a englobar o feminino. E então, ao substituirmos o "os" por "xs", brincamos seriamente com a obviedade de que somos frutos de nossas ações (os bíblicos verbos), que perpassam também os discursos impostos por regras naturalizadas.

${ }^{9}$ Ver SAFATLE, 2016.
} 
e, portanto, não têm a possibilidade de falarem per si, de si e sobre si, como se não fossem agentes de seus devires.

Para viabilizar o exercício da tutela pela Funai, órgão indigenista que assume as funções do $\mathrm{SPI}^{10}$, o Estatuto foi elaborado, contendo normas para o tratamento das muitas relações civis e sociais dos índios, tais como educação, cultura, saúde, bens, terras e áreas de reserva, registro civil, condições trabalhistas, além das normas penais e processuais civis, que serviriam de norte para uma política integracionista.

Para fins de aferição do grau de assimilação a que o indígena estava submetido, o Estatuto do Índio, em seu artigo $4^{\circ}$, categorizou-o em três situações: isolados, em vias de integração e integrados. Tal classificação foi utilizada pela Funai para regular a aplicação da tutela, e serviu de base para a determinação de quais índios ou comunidades estavam aptas a deixar sua condição de relativamente capaz, libertando-se, dessa forma, da tutela indigenista. Há que se notar, porém, que tal classificação se mostra demasiadamente etnocêntrica, tendo em vista que, para ser considerado cidadão de direto, o indígena deveria desfazer-se daquilo que essencialmente o torna índio - a sua indianidade, num processo de aculturação progressivo e definitivo.

Contudo, não se pode querer uma integração aos moldes do etnocentrismo e, ao mesmo tempo, pleitear-se a preservação de uma cultura tradicional ${ }^{11}$, sem recair nas engrenagens contraditórias que são acionadas pelo citado Estatuto. Isso porque, “com o decorrer dos anos, a tarefa de 'preservar uma cultura', tentando ao mesmo tempo integrá-la a outra, revelou-se nada harmônica e, por certo, inviável, uma vez que [a pessoa] não deixa de ser indígena e nem se deixa de ter identidade, a qual é processual e se ressignifica no tempo” (BECKER; SOUZA; OLIVEIRA, 2013, p. 98).

O Estatuto prevê, ainda, a liberação do indígena do regime tutelar, mediante o preenchimento de alguns requisitos, sendo eles: idade mínima de 21 anos; conhecimento da língua portuguesa; habilitação para o exercício de atividade útil, na comunhão nacional; e razoável compreensão dos usos e costumes da comunhão nacional. Tal emancipação poderia ser requisitada a qualquer juiz

\footnotetext{
10 "No Final da década de 60, o SPI enfrentou uma avalanche de denúncias sobre irregularidades administrativas, corrupção, gestão fraudulenta do patrimônio indígena, em especial dos recursos naturais das terras indígenas. Em função disso, o governo federal prometeu esclarecer as denúncias, punir os culpados e criar um novo órgão que faria tudo de modo diferente. De concreto, porém, fez muito pouco. Acabou por extinguir o SPI em 1967, anunciando a criação de um novo órgão para centralizar a prestação de serviços aos povos indígenas. É aí que surge a Fundação Nacional do Índio (Funai), com competência para exercer o papel de tutor dos índios e, dentre outras funções, 'garantir a posse permanente' das terras habitadas pelos índios e o usufruto exclusivo dos recursos naturais nelas existentes” (ARAÚJO, 2006, p. 31).

${ }^{11}$ Sobre isso ver RIBEIRO, 1996.
} 
competente, que, ouvindo a Funai e o Ministério Público, concederia ao interessado a investidura na plenitude da competência civil, sucedendo-se a isso o que transcreve o art. 10 da referida lei:

Art. 10. Satisfeitos os requisitos do artigo anterior e a pedido escrito do interessado, o órgão de assistência poderá reconhecer ao índio, mediante declaração formal, a condição de integrado, cessando toda restrição à capacidade, desde que, homologado judicialmente o ato, seja inscrito no registro civil. (BRASIL, 1973)

Tais condicionantes nada mais são que enunciados da aculturação e assimilação desses indígenas, de modo que o empenho integracionista ainda se vê bastante presente nas diretrizes da Lei 6.001/73, que pretensamente designa o índio como uma categoria a ser extinta, mediante a escolha da usurpação de seu protagonismo ou o abandono de sua identidade étnica. Por mais que afronte a Constituição Federal de 1988, adiantamos que ainda hoje o Estatuto do Índio é aplicado por juízes no Tribunal de Justiça do Mato Grosso do Sul (TJMS), como traz à tona pesquisa realizada por Simone Becker, Olívia Carla Neves de Souza e Jorge Eremites de Oliveira (2013).

\section{A CONSTITUINTE DE 1987-1988: PROTAGONISMO INDÍGENA E LUTA PELOS DIREITOS INDÍGENAS}

Em nossa cena, várias foram as constituições federais que reproduziram o paradigma assimilacionista ao qual a política indigenista brasileira está/estava empenhada. Conta-nos Rosane Lacerda que o constitucionalismo brasileiro esteve atrelado a três elementos fundamentais: "a manutenção da concepção da incapacidade indígena; a disponibilização das suas terras e recursos naturais às pressões econômicas; e a doutrina da segurança nacional.” (LACERDA, 2008, p. 16)

Justamente por essas constituições jamais terem se preocupado em dar voz às lutas travadas pelos povos indígenas e às críticas que o modelo assimilacionista vinha sofrendo desde a década de 1970, quando se seguiram os processos de descolonização, a mobilização política dos povos indígenas, durante o processo constituinte que nos deu a Constituição de 1988, foi bastante intensa.

Em 1971 já havia sido realizado o Simpósio sobre a Fricção Interétnica na América do Sul, em que antropólogos, reunidos nos dias 25 e 30 de janeiro, realizaram uma revisão crítica do tratamento da questão indígena nas Américas, críticas estas que foram dispostas na "Declaração de Barbados I”. Os questionamentos ao modelo indigenista, até então exercido, foram ferrenhos, com destaque à luta pela manutenção da identidade e costumes desses povos, seu direito à organização própria, à garantia do exercício de seus direitos de cidadãos e principalmente do direito ao protagonismo e emancipação (SUESS, 1980). Segundo Rosane Lacerda, o simpósio e a declaração, somados à participação indígena em fóruns de discussão do Sistema das Nações Unidas, que crescia 
à época, acabaram por contribuir com o processo de revisão, em 1986, da perspectiva integracionista contida na Convenção 107 da OIT (LACERDA, 2008, p. 27).

Enquanto isso, no Brasil, o regime militar estava em seu período mais repressivo. Em meio aos “anos de chumbo", permeando as lutas dos movimentos sociais contra a brutalidade da ditadura, as lutas indígenas aconteciam. Em 1973, mesmo ano em que foi promulgado o Estatuto do Índio, foi produzido, por doze bispos e missionários envolvidos com a questão indígena, um documento que coordenaria as ações do Conselho Indigenista Missionário (Cimi), mediante o qual o protagonismo indígena passaria a ser impulsionado rumo ao acesso aos direitos e à reafirmação da identidade desses povos. Tal documento foi intitulado $Y$-juca-pirama - $O$ índio: aquele que deve morrer, e, por meio dele, os religiosos exigiam profundas mudanças no tratamento dispensado às populações indígenas. (LACERDA, 2008, p. 27). É no contexto dessas reivindicações, somando-se aos esforços de demais setores da sociedade envolvente, que, em 1974, foi possibilitada a ocorrência da primeira Assembleia de Chefes Indígenas, marcando o desenvolvimento do protagonismo indígena e sua organização política, antes desconexa.

Dessa forma, o movimento indígena passou a coexistir com as lutas contra o regime militar e pela democratização da nossa Nação, algo que, de maneira detalhada, expõe a antropóloga Graziella Reis de Sant'Ana em sua tese de doutorado (2010). Dentre esses movimentos, cabe destaque aos surgimentos da UNI e da Unind, ambas União das Nações Indígenas, com objetivos que tanto convergem quanto divergem à medida que suas emergências se dão em contextos distintos (SANT’ANA, 2010).

Com o fim do regime militar houve a sensação de liberdade da democracia participativa e plural, e fez-se a necessidade de um novo marco constitucional que fosse ao encontro dos debates aflorados, acerca das liberdades democráticas e do novo conceito do que seria a cidadania. Nesse contexto, ganhou espaço a proposta de representação especial indígena na Constituinte:

A questão seria enfrentada pela primeira vez pelo movimento indígena em julho de 1985 . Reunidos pela UNI em Goiânia, com o apoio do Cimi, um grupo de indígenas tinha por desafio discutir o tema da representação de seus interesses na ANC. Eram líderes dos povos Sateré Mawe (AM), Yawanawá (AM), Tukano (AM), Tikuna (AM), Manchineri (AM), Jaminawa (AC), Apurinã (AC), Kaxarari (AC), Makuxi (RR), Suruí (RO), Guajajara (MA), Tembé (PA), Munduruku (PA), Xokó (SE), Kiriri (BA), Fulni-ô (PE), Guarani-Kaiowá (MS), Kaingang (PR, SC, RS), Terena (MS), Krenak (MG), Bororo (MT), Xavante (MT), Pareci (MT), Umutina (MT), Irantxe (MT), Bakairi (MT), Tapirapé (MT), Ricbaktsa (MT) e Apiaká (MT). Para a maioria, a participação na Constituinte deveria ocorrer "de forma direta, com candidatos escolhidos pelas comunidades, sem vinculação partidária”. (LACERDA, 2008, p. 32) 
Assim, quando em 18 de julho de 1985 foi criada a Comissão Provisória de Estudos Constitucionais, mediante o Decreto $\mathrm{n}^{0}$ 91.450, encarregada de elaborar um anteprojeto de constituição, vários projetos de capítulos foram encaminhados, incluindo aqueles voltados à temática indígena, apoiados por instituições tais como a Conferência Nacional dos Bispos (CNBB) e o Conselho Indigenista Missionário (Cimi), entre muitas outras.

Dez representantes indígenas se reuniriam para participar ativamente do processo constituinte da Associação Nacional Constituinte (ANC), dois de cada região do País, para representar os interesses e lutas de seu povo. A escolha de tais representantes deu-se mediante proposta de Álvaro Tukano, então coordenador da União das Nações Indígenas (UNI). A proposta foi apresentada perante a Comissão Provisória de Estudos Constitucionais, mas foi refutada por Afonso Arinos, presidente da Comissão, sob o argumento de que os interesses indígenas seriam representados na Constituinte pela Funai - legalmente, quem exercia a famigerada tutela indigenista.

De tal forma, a rejeição dessa proposta fez com que a articulação do movimento indígena na UNI, no Cimi, na Comissão Pró-Índio de São Paulo (CPI-SP), no Centro Ecumênico de Documentação e Informação (Cedi) e no Instituto de Estudos Socioeconômicos (Inesc) tentasse o acesso à Câmara Federal, buscando por novas bases jurídico-políticas voltadas às concepções pluriétnica e multicultural do Estado brasileiro.

Assim, nas eleições de 1986 foram lançadas as candidaturas de sete indígenas: Mário Juruna, (PDT-RJ), Marcos Terena (PDT-DF), Álvaro Tukano (PT-AM), Guarani Karaí Mirim (PT-SP), Gilberto Macuxi (PT-RR), Davi Yanomami (PT-RR), Biraci Yawanawa (PT-AC) e Idjahuri Karajá (PMDB-GO). Desses, nenhum acabou eleito, sendo a falta de recursos e de experiência em disputas eleitorais levantada como principal dificuldade enfrentada por esses candidatos (LACERDA, 2008, p. 44). Frustrada mais essa tentativa de representação na ANC, o movimento indígena, junto às entidades civis UNI, Cimi, Inesc, Cedi e CPI-SP, tratou de buscar apoio parlamentar para aprovação de um programa mínimo para os direitos indígenas na Constituinte (LACERDA, 2008, p. 45).

Tal programa, encabeçado pela UNI, foi constituído pelos seguintes pontos: o reconhecimento dos direitos territoriais dos povos indígenas como primeiros habitantes do Brasil; demarcação e garantia das terras indígenas; usufruto exclusivo, pelos povos indígenas, das riquezas naturais existentes no solo e subsolo dos seus territórios, considerando-se que ser indígena é também ser possuído-apropriado pela terra e não proprietário dela; reassentamento, em condições dignas e justas, dos posseiros pobres que se encontram em terras indígenas; reconhecimento e respeito às organizações sociais e culturais dos povos indígenas e a seus projetos, além das garantias de plena e ideal cidadania. 
O programa ganhou apoio parlamentar por meio da Subcomissão de Negros, Populações Indígenas, Pessoas com Deficiência e Minorias, porém, antes da instalação das oito comissões temáticas, como o Regimento da Assembleia Constituinte Nacional (ANC) dividiu os seus trabalhos, coube ao movimento indígena a reformulação e formatação de uma proposta unitária, que acabou por encerrar um conteúdo de alcance mais limitado. É necessário reconhecer que em todo o processo de preparação para a constituinte e até a instalação da ANC, a presença dos indígenas se fez constante. Conta-nos Luíza Meyer que, em todo esse processo, três momentos foram simbólicos e marcantes para o protagonismo indígena:

(1) quando (os indígenas) cercaram o presidente da Subcomissão dos Índios, Deputado Ivo Lech, e o submeteram a uma pajelança para que o espírito bom entrasse em sua cabeça e em seu coração; (2) com a aprovação do capítulo específico “Dos Índios” no texto constitucional, quando festejaram e dançaram com a vitória; (3) e com a supressão do texto do Projeto de Constituição que destinava aos Estados as terras dos aldeamentos extintos, onde, novamente, festejaram com a conquista. (MEYER, 2014, p. 97)

Em todos os passos dados, prenhes de simbolismos, buscavam colocar em evidência a superação da perspectiva assimilacionista, tratando o movimento indígena de apoderar-se de sua indianidade, fato que tornava suas opiniões e vontades visíveis perante a comunidade civil.

Assim, em um trabalho de articulação, movimento político e sensibilização, a população indígena ganhou voz e se fez ouvir no processo constituinte de nosso País. Nesse viés, citamos a atitude histórica de 50 anciãos indígenas, vindos de aldeias do sul do Pará, que, em 18 de março de 1988, adentraram ao Congresso Nacional, fazendo com que o deputado Ulysses Guimarães, eleito presidente da ANC, suspendesse os trabalhos de votação do plenário para recebê-los em protesto contra artigo que excluía da proteção constitucional os indígenas “em elevado estágio de aculturação”. Reivindicaram, ainda, a presença de um artigo que impedisse a exploração mineral em terra indígena.

Também, quando da votação do capítulo intitulado “Dos índios”, delegações indígenas de várias regiões do País acamparam em Brasília, percorrendo os gabinetes dos parlamentares por três semanas, num trabalho de sensibilização ${ }^{12}$. As negociações sobre o capítulo iniciaram-se em 25 de maio de 1988 e a votação só teve início no dia 26 de maio daquele ano, com as conclusões das negociações em 31 de maio, dando a vitória para a persistência indígena (MEYER, 2014, p. 100).

Destacaram-se nesse contexto as ações do cacique kayapó Raoni Mentuktire, que realizou intervenções, por meio de discursos e abordagens de parlamentares, fazendo com que estes

\footnotetext{
${ }^{12}$ Mais recentemente, na discussão da PEC 215, de demarcação de terras indígenas, tais resistências foram empreendidas pelos movimentos indígenas, como aponta em sua dissertação Rayane B. Macedo (2017).
} 
explicassem em detalhes o que ocorria durante as reuniões de negociação de Emenda-Fusão Substitutiva que viria a dar origem ao capítulo “Dos Índios” (LACERDA, 2008, p. 125). Tal emendafusão-substitutiva foi votada no Congresso Nacional em $1^{\circ}$ de julho de 1988, sendo aprovada por 487 votos, havendo cinco contrários e 10 abstenções, afastando-se da proposta inicial as condicionantes de posse imemorial e localização permanente, bem como a tentativa de ainda se tratar os indígenas como relativamente incapazes - com a necessária participação de órgão federal próprio (Funai) em todos os atos que envolvessem interesse das comunidades indígenas, sob pena de nulidade -, aliada à supressão da expressão “originários” quando em tratamento dos direitos indígenas sobre suas terras.

\subsection{A ASCENSÃO DO ÍNDIO À CIDADANIA - CF/88 E CONVENÇÃO No 169 DA OIT - UM CAMINHO QUE SE DESENHA}

A Constituinte de 1988 promoveu um momento bastante oportuno para o desenrolar de discussões sobre os temas relacionados ao indigenismo e às necessidades dos povos indígenas do nosso País, sendo o Congresso Nacional o grande palco dessas discussões, que fizeram da Constituição um grande marco para o direito indígena. Nela, o Estado deixou para trás a velha perspectiva do assimilacionismo, que previa o desaparecimento do índio, assegurando-lhe o direito à terra e à diferença (RAMOS, 2002, p. 35).

A CF/88 causou uma fissura em toda legislação ordinária referente aos indígenas, quando reconheceu o direito de continuarem a ser índios, afastando-se a necessidade de integração à comunhão nacional, bem como ao afirmar sua titularidade de direitos coletivos (MARÉS, 2002, p. 50). Contudo, ainda hoje, apesar de vários projetos apresentados, nenhuma alteração no Estatuto do Índio foi realizada para além da revogação tácita.

Carlos Marés conta-nos que a CF/88 tem deixado "lacunas", na medida em que cria direitos sem, no entanto, os regulamentar, impossibilitando a sua pronta efetividade. O teórico compartilha que “compete aos juristas e ao povo exigir uma interpretação segundo os princípios maiores da Constituição e da sociedade organizada, que privilegiam o coletivo e impõem à propriedade e ao patrimônio individuais a subordinação [...] aos interesses coletivos” (MARÉS, 2002, p. 51). E o que seria isso? Seria, e é, assumir que a lógica das sociedades indígenas opera sob outros ditames que não, por exemplo, da propriedade privada: “Não são poucos os povos indígenas do mundo a afirmarem que a terra não lhes pertence, pois são eles que pertencem à terra” (VIVEIROS DE CASTRO, 2016, p. 19). 
Com relação ao palco internacional, grandes mudanças foram também alcançadas quanto à normativa de proteção aos povos originários, embora em solo nacional o Estatuto do Índio ainda se encontre em vigor, não sendo, ainda, substituído pela lógica holista que atravessa o crer sendo / ser sendo do indígena (VIVEIROS DE CASTRO, 2015, 2016). Após intenso debate, o Brasil ratificou a Convenção 169 da OIT em 2002, por meio do Decreto Legislativo $n^{0}$ 143, que está em vigor desde 2003. A Convenção faz menção aos povos indígenas, e recebeu forte crítica dos setores políticos mais conservadores, pois tratavam-na como oportunidade para que os povos indígenas se tornassem independentes, fracionando o território brasileiro, numa discussão sobre limites e com choque de soberanias.

A demora na ratificação da Convenção, pelo Brasil, deixa patente seu conhecido posicionamento anti-indígena no cenário internacional. Vencida essa barreira, ainda há muito o que se fazer para a implementação eficaz dos preceitos adotados. O Decreto Legislativo $\mathrm{n}^{\mathrm{0}}$ 143, de 2002, incorporou a Convenção ao ordenamento jurídico brasileiro, mas ela ainda carece de mecanismos mais eficazes de aplicação no território brasileiro, sendo esse um grande desafio para o nosso País nos próximos anos.

Desejamos a partir deste momento trazer a temática indígena para o Cone-Sul do Mato Grosso do Sul, onde a maior demanda ainda está localizada nos constantes entraves proporcionados pela visão distorcida da tutela indigenista e dos conflitos fundiários - distorção essa que se dá nas relações interinstitucionais com a Funai, numa constante que atravessa esse órgão indigenista e suas práticas, como esmiuçaremos mais à frente. Como ilustração, considere-se o plano de reestruturação do órgão, que começa com um novo regimento interno e concurso para renovação do quadro funcional, que até então era aproveitado do antigo SPI - algo muito criticado quando de sua fundação.

O caminho da cidadania indígena começa a se traçar mediante um protagonismo de resistência, persistência e re-existência, lutas organizadas em âmbito nacional e local, pois, como bem destaca e ilustra Ana Valéria Araújo (2006, p. 77), “O Executivo insiste em revisar paradigmas revogados de integração, incitando polêmicas desnecessárias que pouco permitem avançar na direção da concretização da concepção contemporânea de igualdade”.

Paralelamente às engrenagens estatais, que ora avançam, ora travam em burocracias advindas das lacunas jurídicas, as capilaridades de agenciamentos dos movimentos indígenas dão aos índios oportunidade de participação efetiva no cenário político brasileiro, como atores de suas próprias histórias, embora haja pela frente algumas questões a serem sanadas, sendo uma delas a "substituição da tutela por outros mecanismos de proteção especial e instrumentos de apoio do poder público aos povos indígenas” (ARAÚJO, 2006, p. 78). Quiçá caiba, também e para além da 
substituição da tutela nesses sentidos engessadores binários, percebermos tal termo como mediação ou ponte, isso porque por meio dessas parcerias dá-se multiplicidade às ações dos agentes indígenas.

\subsection{DA EXPLORAÇÃO DA ERVA MATE À POLÍTICA INDIGENISTA DO ESTADO NOVO - A (DES)CONSTRUÇÃO DO (FARO)OESTE INDÍGENA}

Em 10 de novembro de 1937, Getúlio Vargas, mediante um golpe de estado - como o atual vivido em 2016 pela deposição da presidenta Dilma (Rousseff) -, instituiu o chamado Estado Novo. Com o advento da dita "Era Vargas", tornou-se objetivo fundamental do Estado a exploração e o povoamento do interior do nosso País - movimento que ficou conhecido como "sertanismo", caracterizado pela expansão territorial e colonização do oeste.

O movimento ganhou o rótulo de Marcha para o Oeste e se revestiu da prerrogativa de incorporar os indígenas, já assistidos pelos aparatos estatais via política integracionista (MEYER, 2014), à população rural. Essa ação protecionista se vinculou às teorias do contato cultural e no da $a$ culturação. Assim, pretendia, o Estado, fixar o homem à terra, garantindo a extinção das raízes do nomadismo e transformando os indígenas do oeste brasileiro em “sertanejos” produtivos, com o SPI doutrinando-os na compreensão da importância e da necessidade do trabalho rural. Como p(l)ano de fundo dessa labuta do Estado na política da Marcha para o Oeste, mora(va) também o interesse desse mesmo Estado em (de)ter o controle das suas terras, o que deu-se pela divisão e venda do território ainda não desbravado. Cabe pontuar que, para o geógrafo Ariovaldo Umbelino (2011), até os dias atuais, “Para se ter uma ideia, cerca de 60\% dos imóveis rurais não possuem titulação de fato”.

Tamanho foi o empenho de Vargas, na colonização do Oeste, que a ação ganhou grande relevo na publicidade daquela época, devendo-se muito disso às ações do Departamento de Imprensa e Publicidade (DIP), que procurou glamourizar o índio e as iniciativas governamentais. Assim, Vargas criou, em 1939, o Conselho Nacional de Proteção aos Índios (CNPI), órgão encarregado de promover a conscientização popular sobre a cultura indígena e a política estatal, nomeando Cândido Rondon como diretor (GARFIELD, 2000). Aliás, a despeito das controvérsias, Rondon apresentou ações que o tornaram mítico entre muitos indígenas, com destaque para os Terena, como enaltece a antropóloga Sant’Ana (2010).

A política indigenista da Era Vargas assumiu uma face expansionista, principalmente no que diz respeito ao tratamento da terra. O Estado Novo procurou criar vastas extensões de território indígena, projeto este que se sagrou com a criação do Parque do Xingu - espaço que cumpriria duas importantes funções: preservar a fauna e a flora locais e criar um ambiente onde as comunidades 
indígenas seriam “aculturadas paulatinamente”. Segundo as palavras de Antônio Carlos de Souza Lima:

Até este momento o padrão fundiário implícito à imposição de uma territorialidade aos grupos indígenas supunha [...] a demarcação de pequenas porções de terra em que os grupos indígenas, resumidos muitas vezes à dimensão de famílias nucleares, se fixariam e dos quais extrairiam sua subsistência básica, o mais sendo complementado com a sua inserção no mercado regional de mão-de-obra, mediada pela atuação do Serviço. Os finais da década de 1940/inícios da de 1950 marcariam, porém, uma considerável alteração com as propostas em torno da região do Xingu. (LIMA, 1998, p. 168)

O SPI, juntamente com a Fundação Brasil Central (FBC), criada com o intuito de promover a colonização de grandes porções do centro-oeste brasileiro, atuariam complementarmente, de forma a restituir ao SPI a tarefa de localização de trabalhadores rurais e sua fixação no campo, como mais um incentivo para a promoção do esbulho das terras indígenas, cuidadosamente disfarçado de progresso e povoamento do oeste.

Vale mencionar, contudo, que as terras ocupadas tradicionalmente por populações indígenas já vinham sofrendo avanço do "homem-branco" muito antes. Voltando atrás, poderíamos datar esse avanço desde as primeiras incursões de bandeirantes paulistas, que penetraram no território matogrossense para captação de mão de obra indígena, seguindo pelo sul e oeste, em direção às fronteiras castelhanas. Tal avanço levou ao descobrimento das minas de aluvião, que acabou por atrair os portugueses para o desenvolvimento do bandeirantismo de povoamento (ESSELIN; OLIVEIRA; OLIVEIRA, 2012, p. 71).

Após a Guerra entre Brasil e Paraguai (1864-1870), uma comissão foi organizada com o intuito de demarcar as fronteiras entre os dois países. Tal comissão percorreu a região de ocupação dos Kaiowá e Guarani, entre o rio Apa e o Salto de Sete Quedas, em Guaíra/PR (BRAND et al., 2003). Dessa comissão faziam parte o coronel Enéias Galvão, barão de Maracaju (chefe da expedição); o capitão Antônio Maria Coelho e Thomaz Laranjeira.

Thomaz Laranjeira, ao observar o potencial econômico oferecido pela região, fundou uma fazenda de gado em Mato Grosso, passando, posteriormente, a objetivar a exploração da erva-mate. Assim, usando dos seus contatos com o então alçado presidente da Província, Antônio Maria Coelho, Laranjeira obtém permissão para exploração, sem monopólio, da erva-mate (BRAND et al., 2003).

A área concedida em arrendamento à Cia Matte Laranjeira abrange grande parte do território Guarani e Kaiowá, causando imenso impacto à cultura daquela população, que, em sua maioria, ou foi cooptada para o trabalho na colheita e no preparo da erva-mate ou fugiu para o interior das matas, sendo, muitas vezes, caçada e entregue às reservas ou até morta. O órgão indigenista desempenhou um papel bastante importante nesse período, sobretudo no processo de confinamento dos Guarani e 
Kaiowá nas reservas indígenas, uma vez que, ao “demarcar reservas indígenas, o SPI liberou o restante das terras ocupadas pelos índios, disponibilizando-a para a colonização” (BRAND; FERREIRA, 2009, p. 113).

Compreender esse fato é importante para a percepção de que existe um padrão no lidar com as populações indígenas do centro-oeste do nosso País. Seja na concessão de exploração da terra a particular, seja na expansão territorial promovida pelo governo federal durante o Estado-Novo, a coisificação do índio torna-se necessária para que ele melhor se encaixe nas necessidades que se apresentam a cada momento da política ou história do Brasil.

Manuela Carneiro da Cunha (1994) deixa-nos entrever as linhas abissais ${ }^{13}$ que profundamente marcam as diretrizes do indigenismo brasileiro até então - linhas essas que marca(ra)m o indígena como ser em transição, fadado a abandonar sua identidade e integrar-se à “comunhão nacional”, conforme a necessidade estatal que se apresentar. Ao mesmo tempo, também usamos as linhas abissais porque, onde há linha, há para nós as noções de fuga, de Deleuze e Guattari (1995), de que as inter-relações tendem a disparar o agenciamento dos movimentos capilares que não necessariamente percebemos que provocamos, e que são capazes, em si, de transbordarem as contenções pretensas da estrutura do aparelho de Estado.

\section{PRECONCEITO ÉTNICO E INSTITUCIONAL CAMINHAM LADO A LADO - A ATUAÇÃO DA FUNAI ANTE A CONSTRUÇÃO DA CIDADANIA INDÍGENA NO MUNICÍPIO DE DOURADOS/MS}

Familiarizados que estamos com a colonização do oeste brasileiro, bem como com os percalços encontrados pelos povos indígenas na construção de seus direitos (que com muito esforço alcançaram na Constituinte de 1987/1988), mais tranquilamente conseguiremos visualizar as tramas das redes de acesso à cidadania que procuraremos expor neste item.

Para tanto devemos, primeiramente, analisar o contexto existencial do indígena no município de Dourados/MS. A população indígena do sul do estado de Mato Grosso do Sul é composta, primordialmente, pelos Guarani e Kaiowá, sendo que outras etnias também podem ser encontradas

\footnotetext{
${ }^{13}$ Boaventura de Souza Santos, em artigo intitulado Para Além do Pensamento Abissal: das linhas globais a uma ecologia de saberes, que aparece em obra publicada em conjunto com Maria Paula Meneses- Epistemologia do Sul - (SANTOS, 2010), remonta ao eurocentrismo e atribui a este a desqualificação de toda uma construção de culturas e saberes no período colonial. Citamos aqui tal obra, e escolhemos tal termo, buscando elucidar os dizeres de Boaventura, que nos faz saber que, para o colonizador, a colônia e seus habitantes originários não haviam sido, ainda, domesticados, necessitando da guia e orientação de um Estado considerado civilizado e que já possuía tradição, cultura e conhecimentos científicos consolidados, capazes de suplantar quaisquer outras culturas ou saberes (o dito epistemicídio).
} 
em convívio com os mesmos - é o caso dos Terena, introduzidos na região por ocasião da construção das redes de telégrafo e incorporados pela ação do SPI ${ }^{14}$.

Os Kaiowá e os Guarani tem relação tradicional com a natureza, que se dá de forma distinta da nossa relação. Um dos exemplos é o manejo de recursos e agricultura de coivara, como forma de vitalizar o solo, bem como a metodologia da agricultura de itinerância. Como descrevem Antônio J. Brand e Rosa S. Colman (2008, p. 155), os Guarani e os Kaiowá “faziam suas derrubadas, que eram queimadas, cultivadas e depois de dois ou três anos deslocavam-se para outro espaço, deixando que aquela terra se recuperasse”.

Tais indígenas utilizavam, ainda, como forma subsidiária de sustento familiar, a caça, a pesca e a coleta de frutos e raízes, que eram abundantes na região, e esse meio de vida só era possível porque se tratava de região de vegetação densa, que ocupava vasto território.

Em sua passagem pelo então Mato Grosso, Cândido Rondon chegou a manter contato com os indígenas Guarani e Kaiowá, na região da barra do rio Brilhante: “Nas barras deste rio acham-se localizados os índios Caiuá, da nação Guarani, índios pacíficos e empregados nessa zona na extração e fabrico de herva mate” (RONDON, 1959, p. 101 apud CHAMORRO, 2015, p. 157).

Com relação ao município de Dourados, relatos do indígena Hilário Martines, de aproximadamente 88 anos, fazem crer que o trabalho indígena esteve presente na construção de pontes e estradas, em parceria com o marechal Rondon: “O índio ajudou a fazer a ponte, a estrada. A Avenida Marcelino Pires e a estrada que continua até Rio Brilhante foram feitas por indígenas. Os netos e os bisnetos dos que fizeram a estrada estão no Panambi e no Panambizinho” (CHAMORRO, 2015, p. 157).

Contudo, a atuação do SPI impossibilitou, ao indígena sul-mato-grossense, a manutenção de seu modo de vida tradicional. Brand e Almeida analisaram a demarcação das reservas indígenas de 1928 e concluíram que “em nenhum momento houve interesse por parte desse órgão (SPI) em procurar saber realmente onde se localizavam as terras de ocupação tradicional destes índios ou qualquer preocupação na definição dessas reservas indígenas como a organização social dos mesmos” (BRAND; ALMEIDA, 2007, p. 5).

\footnotetext{
${ }^{14}$ Especificamente em Dourados, os deslocamentos se deram por ocasião da participação desses indígenas (terena) na implantação da rede de telégrafo que chegou até as cidades brasileiras que fazem fronteira com o Paraguai. Após a finalização dos trabalhos, esses indígenas foram incorporados como trabalhadores nas fazendas que foram implantadas na região (MEYER, 2014, p. 154).
} 
Nos dias de hoje, poucos são os indígenas Guarani e Kaiowá que conseguem manter o seu esquema tradicional de sustento e de produção, devido ao fato de que as áreas por eles habitadas não oferecem as condições necessárias ao desenvolvimento de seu modo de vida original:

Há um crescente número de pessoas que depende quase integralmente do trabalho assalariado, dos serviços prestados nas propriedades vizinhas e em outros estados, das aposentadorias, da prestação de serviço na área pública e privada e dos programas de assistência do governo. (CHAMORRO, 2015, p. 235)

Apesar de toda essa transformação, geradora da dependência de recursos externos à comunidade indígena, podemos presenciar no dia a dia das interações interpessoais a manutenção de relações que traduzem a tradicionalidade social entre esses indígenas, dentro e fora da comunidade. “Os Kaiowá, como os outros povos guarani falantes, destacam-se entre os povos indígenas por resistirem ao longo contato com a sociedade não indígena, mantendo sua unidade política, sua língua e sua religião, em situações cada vez mais adversas” (CHAMORRO, 2015, p. 236).

Em síntese, deve-se mencionar que esses povos “chegaram ao século XXI em pleno crescimento demográfico, com consciência histórica e política e com competência para o futuro” (CHAMORRO, 2015, 238), fazendo-nos ver que a resistência indígena não se fundamenta na possibilidade de absorção ou não de elementos de outras culturas, mas na forma como esses elementos são reorganizados e aproveitados positivamente por esses povos.

Infelizmente, alheia a todas essas nuances da resistência dos povos indígenas pelo alcance da dignidade de uma cidadania que os contemple com toda a sua diferença, a população do município de Dourados, em grande medida (re)itera rotulações e estigmatizações contra eles, disseminando preconceitos no caminho já composto de percalços do indígena sul-mato-grossense.

Ao mesmo tempo, convém suscitarmos que ao órgão indigenista, a Funai, sobra a crítica pelo “problema indígena no MS”; ou seja, o índio é alavancado ao status de "problema”, e a Funai acusada de não cumprir seu papel de “tutor” - crítica esta que permeia e atrapalha as relações interinstitucionais entre a fundação e outros órgãos.

\subsection{ANÁLISE DAS ATRIBUIÇÕES DA FUNAI COMO ÓRGÃO DE PROMOÇÃO E FISCALIZAÇÃO DOS DIREITOS INDÍGENAS - O FIM DA TUTELA}

Com a promulgação da Constituição de 1988 e do Decreto Presidencial n ${ }^{0}$ 5.051/04, referente à Convenção ${ }^{0} 169$ da OIT, foi garantido o direito de autonomia aos povos indígenas, o respeito à forma de vida e organização peculiar de cada povo, à consulta prévia às intervenções que 
recaiam sobre suas terras e onde vivem, entre outros pressupostos legais que se afastam dos antigos ideais de assimilação, superioridade ou dominação eurocêntricos.

Com isto, novos parâmetros para a política indigenista, aplicados pela Funai, tiveram que ser construídos, relativizando-se muitos dos institutos dos quais esse órgão lançava mão quando em atuação na defesa dos direitos indígenas, como a tutela. Abriu-se espaço, na teoria das teses legais, para o protagonismo indígena, reconhecendo-se a esses povos a autonomia diante da gestão de sua vida civil, na busca pela participação de uma cidadania plena.

Como já exposto, a política indigenista era ambígua no reconhecimento das especificidades culturais dos indígenas, pois se prestava a protegê-las, ao mesmo tempo que tinha por objetivo a integração dessas sociedades à comunhão nacional. A função da tutela era a arma concedida ao órgão indigenista para reforçar uma relação paternalista e intervencionista do Estado para com os índios, mantendo-os submissos e dependentes porque (sobretudo) calados ou não ouvidos.

Relembremos que o processo de democratização do Estado brasileiro, na década de 1980, permitiu uma reavaliação da questão indígena, mediante a ampla participação dos movimentos indígenas e da sociedade civil em todo esse processo, fomentando a organização e participação política dos índios em assuntos de seu interesse. A própria Funai, em seu site, menciona que

[...] a constituição de 1988 instaurou um novo marco conceitual, substituindo o modelo político pautado nas noções de tutela e de assistencialismo [...]. Assim, estas mudanças [...] de abordagem que devem orientar a ação do Estado exigiram uma reformulação dos seus mecanismos de ação relativos às populações indígenas (FUNDAÇÃO NACIONAL DO ÍNDIO, 2012).

Em 2009, foi editado o Decreto $\mathrm{n}^{0}$ 7.059, que iniciou um processo de reestruturação/reformulação da Funai e de sua atuação, na tentativa de inserir o órgão na nova estrutura trazida pela CF/88. Posteriormente, mais precisamente em 2012, tal decreto foi revogado pela promulgação de um novo, de $n^{0} 7.778$. Este apresenta, em seu artigo $2^{\circ}$, as finalidades do órgão indigenista. Destacamos que entre as finalidades elencadas o texto é claro ao afirmar que à Funai cabe “proteger os direitos dos povos indígenas, em nome da União” e "Garantir a participação dos povos indígenas e suas organizações em instâncias do Estado que definam políticas públicas que lhes digam respeito” (BRASIL, 2012).

Assim, a Funai abandona seu papel de tutora do indígena e passa, no plano ideal legislativo, a ser órgão de promoção e fiscalização dos direitos indígenas. Um dos seus deveres é a garantia do acesso e participação dessas comunidades aos mecanismos estatais que promovam e definam as políticas públicas que lhes digam respeito, um "limite” ao órgão indigenista, no sentido de que este não representa mais essas comunidades na defesa de seus interesses, sendo responsável apenas por 
garantir-lhes o protagonismo, onde ele for necessário, como bem analisou Gilberto Azanha, coordenador do Centro de Trabalho Indigenista (FUNDAÇÃO NACIONAL DO ÍNDIO, 2010). Ou seja, a Funai, carrega(va) em si a tutela indigenista, não só juridicamente, mas no trato das demandas cotidianas, na pessoa dos seus servidores, devendo na maioria das vezes representar, por procuração via cartório (por instrumento público), o indígena. O reflexo da mudança do paradigma indigenista, trazido pela CF/88, fez-se sentir desde a raiz do órgão, que é sua fundamentação legal, até os ramos de sua atuação, no trato direto com as comunidades indígenas, por meio do Posto Indígena, que passou a se chamar Coordenação Técnica Local (CTL).

Não é de se estranhar o fato de que esta reestruturação tenha trazido diversos transtornos no trato com a comunidade civil "não indígena”, uma vez que a Funai deixa de cumprir funções que foram realocadas, ou até extintas, juntamente com a concepção da tutela. Ainda que tal reestruturação tenha se dado sem a participação do movimento indígena, entendemos razoável o argumento de Azanha (FUNDAÇÃO NACIONAL DO ÍNDIO, 2010), de que o movimento indígena não possuía posicionamento definido quanto ao órgão indigenista, tornando inviável, naquele momento, a ampla discussão sobre o tema. Contudo, não podemos afastar a possibilidade de haver uma nova análise da estrutura do órgão, uma vez superada, pelas comunidades indígenas, a noção de tutela, em especial quando nosso olhar é guiado pelo perspectivismo.

Nesse sentido, um importante passo foi dado em 2010, quando um novo concurso para servidores foi realizado pelo órgão, permitindo uma ventilação dos novos parâmetros trazidos pela CF/88 e pela Convenção n ${ }^{\circ} 169$ da OIT. Quando novos indigenistas assumem seus cargos, tendem a vir despidos dos vícios do antigo SPI, passando, neste ponto, a lidar com a temática indigenista sob a égide dos princípios constitucionais.

Assim, as emblemáticas demandas territoriais e sociais, principalmente no que se refere ao Mato Grosso do Sul, passam a ser vistas por vezes, de fato, sob uma nova luz. E, nesse momento, começa a saltar aos olhos um velho problema, que se torna cotidiano para o órgão indigenista: o racismo institucional e/ou racismo de Estado (FOUCAULT, 2010). Se é índio, a demanda é da Funai; mas, uma vez que ela não se presta mais a tutelar o indígena, para que ela serve afinal? Esse é um questionamento com o qual o órgão constantemente se vê às voltas, quando em articulações institucionais. Ora, a resposta mais simples, que nos vem no momento, é: A Funai tem por finalidade promover, fiscalizar e garantir o acesso das comunidades indígenas aos seus direitos, sem ter com isso a prepotência de tomar-lhes o protagonismo.

O advogado e pesquisador Vilmar Martins Moura Guarany, em texto denominado Desafios e Perspectivas para a Construção e o Exercício da Cidadania Indígena, trouxe vários casos que 
demonstram esse entrave. Ater-nos-emos a um deles, para exemplificarmos o racismo institucional e/ou de Estado - derivado do preconceito étnico, porquanto fica-nos patente que tais impedimentos são impostos apenas aos indígenas pelo fato de o serem, e então escorrendo para a própria Funai. Vejamos:

Caso $n^{0} 1$ - No final de 2004, várias manifestações de professores e agentes de saúde (indígenas) e de outros servidores públicos índios e não-índios traziam a informação de que, nos estados de Mato Grosso e Mato Grosso do Sul, as agências do Banco do Brasil e da Caixa Econômica Federal estavam anunciando que todos os índios com contas naqueles bancos deveriam, para regularizá-las, ao apresentar documento expedido pela FUNAI - ou alvará judicial, ou ainda carta de Emancipação de Tutela - sob pena de terem suas respectivas contas encerradas até o final do ano. (GUARANY, 2006, p. 158)

Desse caso destacado, e dos outros dois casos apresentados pelo autor (GUARANY, 2006, p. 158-159), fica claro que a noção da tutela indigenista não abandonou as práticas das entidades civis. O próprio autor conclui que existe um desconhecimento da legislação indigenista ou má-fé nas relações com o indígena, uma vez que à Funai não cumpre qualquer tipo de interferência no trato de negociações civis realizadas pelo cidadão indígena. Isso se dá porque a atribuição do órgão indigenista, no imaginário popular, ainda se encontra fortemente atrelada aos desígnios da tutela indigenista. Por óbvio, não se pode furtar a Funai da fiscalização de tais relações, mas a sua atuação se limita pelo protagonismo indígena em exercício da sua cidadania, que, quando impedido, exige a atuação do Ministério Público Federal (MPF), juridicamente:

Feitas essas considerações e tomando por base a legislação em vigor no Brasil, podemos afirmar que não há nenhum fator legal, moral, religioso ou relativo a quaisquer argumentos, que possa impedir os povos indígenas de exercerem a sua capacidade civil plena. Mesmo aqueles povos com algum grau de dificuldade de compreensão em relação aos valores e ao modus vivendi do restante da sociedade nacional têm autonomia, se assim o quiserem, para pôr em prática todos os direitos inerentes ao exercício da cidadania. (GUARANY, 2006, p. 163)

Podemos ver, nestes exemplos, a prática do preconceito institucional, responsável por alijar o indígena do alcance de direitos que deveriam ser comuns a todos os cidadãos brasileiros. $\mathrm{O}$ problema parece se expandir quando analisamos o acesso do índio aos benefícios do Instituto Nacional do Seguro Social (INSS), ou às políticas públicas que deveriam alcançá-lo, tal qual o Programa Nacional de Fortalecimento da Agricultura Familiar - Pronaf, do qual o indígena é afastado pela noção, pelo órgão que promove tal programa, da existência da tutela indigenista.

Mas por que ressuscitar um instituto já tão (de)batido e obviamente revogado pela Lei Maior de nosso Estado nacional, no sentido mais restrito de subserviência? Parece-nos óbvio que o tratamento diferenciado do indígena, no estado de Mato Grosso do Sul, se dá, tão somente, pelo ranço do preconceito étnico, uma vez que o estado vive em constante dualidade quanto às questões 
indígenas, sendo a mídia jornalística local uma das maiores responsáveis por difundir esta prática nefasta.

Em artigo publicado em 2012, Laura Cecília López escreve que, durante o século XIX, o Brasil viveu um processo de construção ideológica que, assim como em outros países da América Latina, se fazia crer em uma nação mestiça, sustentando que isto deu-se de forma harmônica, fundando uma democracia racial ${ }^{15}$. A autora menciona que tal "harmonia racial" tinha como pressuposto uma "manutenção das hierarquias raciais vigentes no país, na qual o segmento branco da população foi tido como principal e dominante” (LÓPEZ, 2012, p. 123).

Assim, entendemos a prática do racismo institucional como historicamente fomentada pelo Estado, pois sua prática reitera um ideal de hierarquia racial, operado desde os tempos da colônia. As próprias políticas públicas estatais, voltadas para a correção dessa dívida histórica, são formas de confissão do Estado, que se compromete a realizar uma compensação pelos seus erros. O Instituto da Mulher Negra (Geledés), em parceria com o Centro de Estudo e Assessoria (Cfemea), lançou o Guia do Enfrentamento ao Racismo Institucional, no qual afirma que:

O conceito de Racismo Institucional foi definido pelos ativistas integrantes do grupo Panteras
Negras, Stokely Carmichael e Charles Hamilton em 1967, para especificar como se manifesta
o racismo nas estruturas de organização da sociedade e nas instituições. Para os autores,
"trata-se da falha coletiva de uma organização em prover um serviço apropriado e
profissional às pessoas por causa de sua cor, cultura ou origem étnica”. (GELEDÉS, 2013, p.
11)

Tais subtrações à cidadania indígena ferem diretamente o princípio nuclear da CF/88, bem como dos direitos humanos, qual seja: a dignidade da pessoa humana como principal objetivo do Estado. Nesse sentido, somos novamente arrastados para a antiga discussão cientificista do século XIX, que se preocupava com a demarcação entre antropoides e humanos ${ }^{16}$, mas dessa vez com um viés de cidadania, de alcance de uma capacidade civil plena, retomando a discussão de Varnhagen, que afirmou que a raça índia não seria capaz de se desenvolver no meio da civilização.

Manuela Carneiro da Cunha afirma que "essas ideias, que atribuem à natureza e à fatalidade de suas leis o que é produto de política e práticas humanas, são consoladoras para todos à exceção de suas vítimas” (CUNHA, 2012, p. 60). Retomamos essa discussão de forma a demonstrar o excesso de marginalização que essas “pequenas desvirtuações” do protagonismo indígena acabam por cometer. Afinal, se somos todos humanos, a todos cabem os direitos garantidos pela legislação estatal,

\footnotetext{
${ }^{15}$ Cf. ainda BECKER; SOUZA; OLIVEIRA, 2013.

${ }^{16}$ Manuela Carneiro da Cunha, discutindo a humanidade que historicamente se vinculou ao indígena, conta-nos que “a humanidade dos índios era afirmada oficialmente, mas, privadamente ou para uso interno no país, a ideia da bestialidade, da fereza, em suma, da animalidade dos índios, era comumente expressa” (CUNHA, 2012, p. 58).
} 
não sendo aceitável que caia alguma letra da lei para aqueles que, somente por ostentarem uma identidade própria e distinta, são desconsiderados como cidadãos.

\subsection{PROCESSO NO 08788.000038/2016-50 - UM MERGULHO NAS LINHAS ABISSAIS DO RACISMO INSTITUCIONAL}

Para promover uma melhor visualização daquilo que estivemos analisando neste artigo, necessário se faz que adentremos nas águas profundas que dividem índios e não índios para o Estado brasileiro. Assim o faremos por meio da análise discursiva do processo administrativo $\mathrm{n}^{0}$ 08788.000038/2016-50, sob a responsabilidade da Coordenação Regional de Dourados/MS, com a finalidade de realizar consulta à Procuradoria Federal Especializada (PFE), atuante naquela Regional, acerca dos procedimentos para emissão da Declaração de Aptidão do Programa Nacional de Fortalecimento à Agricultura Familiar (DAP), esclarecendo, dessa forma, divergências com a Agência de Desenvolvimento Agrário e Extensão Rural - Agraer, do estado de Mato Grosso do Sul.

O Programa Nacional de Fortalecimento da Agricultura Familiar - Pronaf - nasceu por meio do Decreto $\mathrm{n}^{0}$ 1.946, de 28 de junho de 1996, objetivando “promover o desenvolvimento sustentável do meio rural, por intermédio de ações destinadas a implementar o aumento da capacidade produtiva, a geração de empregos e a elevação da renda, visando a melhoria da qualidade de vida e o exercício da cidadania dos agricultores familiares” (Art. $1^{\circ}$ do Decreto $\left.n^{\circ} 1.946 / 96\right)$. Após isto, o Pronaf adaptou-se e reformulou-se para promover uma maior inclusão de classes e agentes econômicos que não estiveram abrangidos nos seus primeiros momentos.

Em 2001, o programa passou a ser regido pelo Decreto $n^{0} 3.991$, de 30 de outubro, que traz em seu artigo $5^{\circ}$ a caracterização do grupo a ser beneficiado pelo programa, por meio de requisitos tais que o restringe àqueles que não possuam título de área superior a quatro módulos fiscais, cuja mão de obra seja predominantemente familiar, que obtenham renda advinda das atividades vinculadas ao estabelecimento ou empreendimento, e que residam no local de desenvolvimento das atividades.

É no parágrafo único desse artigo que a figura do indígena, como beneficiário do programa, aparece: “são também beneficiários do Programa os aquicultores, pescadores artesanais, silvicultores, extrativistas, indígenas, membros de comunidades remanescentes de quilombos e agricultores assentados pelos programas de acesso à terra do MDA” (grifo nosso) - desde que esses possíveis beneficiários preencham os requisitos elencados.

Segundo o Ofício nº 35/GAB/CR-DOU/MS/FUNAI/2016, da Coordenação Regional de Dourados, anexo ao referido processo, a DAP é o documento público destinado a identificar as 
unidades familiares de produtores rurais, exigida como requisito para inserção dos grupos familiares em programas e benefícios lançados pelo governo federal, tais como o Programa de Aquisição de Alimentos (PAA), o Programa Nacional de Alimentação Escolar (PNAE), projetos de Assistência Técnica e Extensão Rural (ATER) subsidiados pela Secretaria Especial de Agricultura Familiar e do Desenvolvimento Agrário (Sead), antigo Ministério do Desenvolvimento Agrário (MDA) e o Programa Nacional de Habitação Rural (PNHR). A DAP se faz necessária, ainda, para a inscrição na Agência Fazendária Estadual (AGENFA), o que possibilita a emissão de notas fiscais na comercialização dos produtos agrícolas fora do mercado institucional.

A DAP, em sua forma convencional, por força do que consta no artigo $7^{\circ}$ do referido decreto, que reconhece como integrantes do programa os órgãos das três esferas de governo, devendo ser emitida por órgão que tenha celebrado convênio com a União, o qual exercerá este ato administrativo de forma vinculada. No estado de Mato Grosso do Sul, esse ato vem sendo executado pela Agência de Desenvolvimento Agrário e Extensão Rural (Agraer), autarquia estadual a quem foi dada tal responsabilidade.

Contudo, em 27 de novembro de 2012, o MDA publicou a portaria n 94, que institui a DAPI, destinada tão somente a identificar os indígenas por meio de suas unidades familiares, conforme o artigo $1^{\mathrm{o}}$ da mencionada portaria. Eis a marca que torna alienígena o próprio indígena, talvez em publicação discriminatória desnecessária. Sabe-se, porém, que tal portaria manifesta de forma expressa, por meio do parágrafo $1^{\circ}$ do seu artigo $2^{\circ}$, restrição quanto à política de acesso ao crédito rural, carro-chefe do Pronaf, o que a diferencia drasticamente da DAP convencional. De igual modo, a DAP-I distingue-se na competência de sua emissão, ficando esta exclusivamente a cargo da Funai, segundo o que consta no art. $4^{\circ}$ da mencionada portaria. Vamos aos fatos.

Posteriormente à publicação da portaria $n^{0} 24$ de 2012, a Agraer encaminhou ofício ${ }^{17}$ à Coordenação Regional da Funai em Dourados, comunicando que, dada a existência de portaria que institui a elaboração de Declaração de Aptidão ao Pronaf específica para os indígenas, a agência deixaria de prestar atendimento a eles. Tal decisão, apresentada nesse ofício, deu-se a despeito de a agência reconhecer, no mesmo documento, que a DAP-I não garantiria o acesso dos indígenas ao crédito rural, sendo, portanto substancialmente distinta da DAP convencional. Assim, a agência informou, ainda, que passaria a orientar os indígenas que a procurassem, para que eles se dirigissem à Funai em busca da emissão da DAP-I. Frise-se: sem os atender com a emissão da DAP convencional.

\footnotetext{
${ }^{17}$ Of/AGRAERDOURADOS 005/13, de 25 de março de 2013.
} 
Ao se questionar a agência sobre essa decisão, houve manifestação, por meio de mensagem de e-mail (agraerlocaldourados@hotmail.com), recebida em dia 15 de março de 2013, na qual deram ciência de que aquela agência passaria a emitir a DAP para os indígenas, somente com o propósito de atender ao Programa de Aquisição de Alimentos, desde que a Funai fornecesse Declaração de Produtor Rural, na qual se declarasse a posse da terra e a vinculação do indígena à organização/associação formalizada.

Desta forma, a Agraer acabou por restringir o atendimento ao indígena à ação primária do órgão indigenista, ou seja, a emissão da DAP convencional só seria possível mediante o encaminhamento prévio de lista elaborada pela Funai, contendo os dados dos indígenas que fariam jus à declaração. O indígena por si só não poderia requerer a declaração na agência, devendo antes dirigir-se à Funai para apresentar sua demanda.

Mediante tal exigência, a Coordenação Regional de Dourados realizou consulta à sede da Funai em Brasília/DF, por meio da sua Coordenação Geral de Etnodesenvolvimento (CGETNO), sobre as tratativas realizadas com o MDA, a respeito da emissão das duas DAP. Em resposta, a Funai, por meio de memorando ${ }^{18}$, esclareceu que “é atribuição exclusiva desta Fundação, somente a emissão da DAP-I, não havendo impossibilidade, portanto, de que outros órgãos/entidades emitam a DAP tradicional que dá acesso às operações de crédito, pois ambas possuem características diferenciadas”.

Várias tentativas de se definir as competências de ambos os órgãos foram realizadas, mediante reuniões, contatos telefônicos e troca de ofícios e mensagens de e-mail, sem que nenhum denominador comum fosse encontrado. Em nove de março de 2016, a Agraer emitiu ofício ${ }^{19}$ esclarecendo o posicionamento quanto à emissão da DAP convencional, nada modificando quanto à orientação de que os indígenas interessados na DAP seriam/serão orientad $x$ s a procurar a autorização formal da Funai. A Agraer finalizou o ofício reforçando que

[...] em respeito ao previsto na legislação vigente, o técnico emissor de DAP está autorizado a apenas analisar a possível emissão de DAP a partir de ofício da Funai à Diretoria da Agraer, e apenas para os indígenas incluídos em relação em que deverá constar os nomes dos indígenas, CPF, aldeia e município de moradia (grifo nosso).

Dessa forma, resume-se a problemática numa óbvia desvirtuação do protagonismo indígena, configurada na tentativa de ressuscitar o instituto da tutela indigenista no sentido engessado do termo, privando a população indígena do exercício de sua cidadania, a partir do momento em que essa

\footnotetext{
${ }^{18}$ Memorando n ${ }^{\circ}$ 343/2013/CGETNO/DPDS/FUNAI-MJ, de 18 de abril de 2013.

${ }^{19}$ Ofício no 495/GAB/AGRAER, de 9 de março de 2016.
} 
população não poderá, por si mesma, buscar o acesso ao seu direito de usufruir de programa que a contempla. Três aspectos desse fato devem ser considerados:

1- Existência de convênio entre a Agraer e a União para emissão da Declaração de Aptidão ao Pronaf, para todos aqueles que se enquadrem nos requisitos do artigo $5^{\circ}$ do Decreto $\mathrm{n}^{0} 3.991$ de 2001, abrangendo-se expressamente os indígenas no parágrafo único desse artigo;

2- Existência de duas DAP de características diferenciadas, uma de acesso geral, com garantia plena - aqui tratada como “convencional” -, e outra de acesso somente pelo indígena, com garantias limitadas, expedida tão somente pela Funai;

3- Negação de atendimento ao público indígena, pela autarquia estadual responsável pela emissão da DAP convencional, sem que a Funai se preste a emitir declaração de produtor rural, declaração esta que não encontra correspondente no caso de não indígenas.

A consulta realizada pela Coordenação Regional de Dourados à Procuradoria Federal Especializada, atuante junto àquela Regional, resultou no Parecer $n^{0}$ 03/2016/PFEFUNAI/DOURADOS/MS/PGF/AGU, de oito de março de 2016. Por meio deste parecer, o procurador federal em exercício à época, Eduardo Raffa Valente, analisou os dispositivos legais referentes ao Pronaf e à emissão da DAP, concluindo pela inconstitucionalidade da exigência, realizada pela Agraer, de intermédio da Funai, na emissão da DAP convencional. O parecer ressalta:

A exigência da intermediação da Funai, seguida pela “Declaração de Produtor Rural” pela entidade federal, viola tanto o princípio da legalidade geral quanto o princípio da legalidade específica, prescritos, respectivamente, nos artigos 50, inciso II, e 37 da Lei Fundamental, uma vez que não há qualquer norma que permita à Funai a emissão da mencionada declaração, assim como também inexiste base legal à exigência operada pela entidade estadual, inobstante à competência da Agraer em verificar a possível subsunção da entidade familiar às disposições legais. (Parecer $n^{\circ}$ 03/2016/PFEFUNAI/DOURADOS/MS/PGF/AGU em processo administrativo $n^{\circ}$ 08788.000038/201650)

Devemos, ao analisar o caso apresentado, lembrar-nos de que o instituto da tutela, trazido pela Lei 6.001/73, deixou de ser recepcionado pelo nosso ordenamento jurídico quando da promulgação da Constituição de 1988, de forma a garantir ao indígena uma série de novas prerrogativas da vida civil e do exercício de sua cidadania, antes não desfrutadas devido à capacidade relativa que lhe era atribuída, conforme já mencionado neste artigo.

Desta maneira, a insistência da agência, em fazer-se intermediar pelo órgão indigenista, além de não encontrar fundamento legal, fere alguns dos princípios constitucionais, como os mencionados no excerto do parecer, transcrito acima, bem como relega o indígena aos caminhos de uma burocracia ilegítima e mal-intencionada. Da mesma forma, não podemos dizer que a interferência da Funai neste 
ato se daria com o propósito de resguardar o direito à diferença, uma vez que tal direito visa promover o respeito à diversidade de organizações sociais e culturais, no que tal exigência nada agrega.

Resta-nos cada vez mais próxima a figura do racismo institucional (nos moldes do racismo de Estado foucaultiano), uma vez que a negativa do atendimento resulta da identidade étnica de uma população específica, questão que ainda se encontra em discussão, não se tendo chegado a uma conclusão, fato que impossibilita o acesso de toda essa população a um programa que deveria lhe contemplar, sem que grandes desdobramentos resultassem disso.

Após emissão do referido parecer, e sustentada por ele, a Coordenação Regional de Dourados emitiu ofício à Procuradoria Seccional Federal (PSF), solicitando a análise da questão para que se procedesse ao ajuizamento de ação civil pública contra a Agraer, “com o escopo de cessar os abusos cometidos aos interesses transindividuais em discussão”20, colocando em prática a sua função de fiscalizadora e promotora de acesso a direitos, buscando afastar quaisquer resquícios da tutela indigenista.

O registro desse caso, que ainda se encontra em andamento, pode ser acessado mediante solicitação de visualização do mencionado processo administrativo, diretamente na Coordenação Regional de Dourados/MS, motivo pelo qual não seguem anexos os documentos mencionados, mas tão somente a autorização de consulta expedida pelo então coordenador regional substituto, Vander Aparecido Nishijima.

\section{CONCLUSÃO}

A construção da cidadania indígena se dá todos os dias no estado de Mato Grosso do Sul ao procurar um trabalho, ao frequentar uma universidade, ao buscar a sua subsistência, o indígena sul-mato-grossense enfrenta muitos percalços que se pretendem inerentes à sua identidade étnica. Sob uma análise mais cuidadosa, tais entraves acabam por se mostrar como uma maldosa subversão dos valores e princípios fundamentais trazidos pela Constituição Federal de 1988, como numa tentativa de desumanizar e marginalizar o indígena, subtraindo-lhe o protagonismo.

Nesse aspecto, os exemplos apresentados no percurso deste artigo tendem a demonstrar o quão inserto está o racismo institucional no tratamento das demandas indígenas no Mato Grosso do Sul - racismo que causa entraves ao acesso de direitos, reforçando e sendo reforçado pelo preconceito étnico.

\footnotetext{
${ }^{20}$ Ofício no $^{\circ}$ 112/GAB/CR-DOU/MS/FUNAI/2016, de 22 de março de 2016.
} 
Nesse contexto, as ações da Funai são de fundamental importância, devendo ser pensadas e calculadas para que o órgão indigenista não seja responsável por perpetuar a ideia da tutela representativa adotada pela política indigenista brasileira pré-Constituição de 1988. Nem ainda deve eximir-se a Funai de sua função de órgão fiscalizador e promotor de direitos indígenas, devendo buscar articulações que promovam o protagonismo participativo dessas pessoas, a fim de permitir que elas exerçam sua cidadania.

A Constituição Federal de 1988 ventilou novos parâmetros para a política indigenista brasileira, sendo um dos seus principais feitos o reconhecimento, às comunidades indígenas, da capacidade civil plena. Não só o contexto jurídico sofre diretamente a mudança dessa prerrogativa, mas o social e político também acabam por exigir uma transformação, causando tensionamentos nas relações institucionais, que se encontram debatidas e enfrentadas cada vez mais firmemente.

Reforçamos que, na maior parte das vezes, o racismo institucional se atrela a dispositivos jurídicos que, embora inconstitucionais, ainda se encontram em vigor, como é o caso do Estatuto do Índio, promulgado em 1973 - período em que a ditadura militar incorporava à política indigenista ideais assistencialistas e integracionistas, com um claro desejo de fazer desaparecer a figura do índio, incorporando-o a uma “comunhão nacional” que não prezava pela dignidade humana nem mesmo daqueles já considerados cidadãos plenos, quanto mais do indígena, então considerado um ser transitório, para não falar inumano.

Assim, este artigo buscou despertar-nos para os percalços ainda encontrados no trato da questão indígena em decorrência do constante ressurgimento da tutela indigenista, em seu sentido mais estrito de representação e usurpação do protagonismo indígena, avaliando-se a prática da Agraer como exemplo desta problemática.

Menos em tom de conclusão, e mais de sugestão, sinalizamos que, para fazer cessar tais condutas, será necessária a adoção de uma postura firme pela Funai, não em tomar para si o papel do indígena, mas em fazer com que este seja respeitado em sua cidadania, mediante o questionamento e o enfrentamento, no movimento indígena, de demandas ilegítimas como a aqui apresentada.

Para tanto, reconhecemos a necessidade de uma reforma na legislação vigente, para que seja promulgado (quiçá) um novo Estatuto do Índio, adaptado não somente aos moldes da Constituição Federal de 1988, mas que vá além e preze pela solução das demandas que as comunidades indígenas brasileiras, na especificidade de suas relações sociais e territoriais, requerem. 


\section{REFERÊNCIAS}

ARAÚJO, Ana Valéria. Povos Indígenas e a Lei dos "Brancos”: o direito à diferença. Brasília: Ministério da Educação, Secretaria de Educação Continuada, Alfabetização e Diversidade; LACED/Museu Nacional, 2006.

BECKER, Simone; OLIVEIRA, Déborah G. Análise sobre a (não) caracterização do crime de racismo no Tribunal de Justiça de São Paulo. Estudos Históricos, v. 26, p. 451-470, Rio de Janeiro, 2013. Disponível em: <https://goo.gl/E9jNPM>. Acesso em: 10 mar. 2014.

BECKER, Simone; SOUZA, Olivia Carla Neves de; OLIVEIRA, Jorge Eremites de. A prevalência da lógica integracionista: negações à perícia antropológica em processos criminais do Tribunal de Justiça do Mato Grosso do Sul. Etnográfica, Lisboa, n. 17. v. 1, p. 97-120, 2013.

BRAND, Antônio et al. Os Kaiowá e Guarani em Tempos da Cia Matte Laranjeira. In: ANPUH XXII Simpósio Nacional de História. João Pessoa, 2003.

BRAND, Antonio; ALMEIDA, Fernando Augusto Azambuja. A Desterritorialização dos Kaiowa e Guarani e a liberação de terras para a colonização, no MS. In: Seminário Povos Indígenas e Sustentabilidade: saberes locais, educação e autonomia. Campo Grande: UCDB, 2007. Disponível em: <https://goo.gl/cPPbHg>. Acesso em: 20 set. 2016.

BRAND, Antônio; COLMAN, Rosa Sebastiana. Considerações sobre Território para os Kaiowá e Guarani. Revista Tellus UCDB, ano 8, n. 15, p. 153-174. Campo Grande, 2008.

BRAND, Antônio; FERREIRA, Eva Maria Luiz. Os Guarani e a Erva Mate. Revista Fronteiras, v. 11, n. 19. Dourados, 2009. Disponível em: <https://goo.gl/jZorUU>. Acesso em: 28 set. 2016.

BRASIL. Decreto no 7.778, de 27 de julho de 2012. Disponível em: <https://goo.gl/tPBpz7>. Acesso em: 20 out. 2016.

BRASIL. Lei 3.071, de $1^{0}$ de janeiro de 1916. Código Civil Brasileiro. Disponível em: $<$ https://goo.gl/6FYWBX>. Acesso em: 30 set. 2016.

BRASIL. Lei $\mathbf{n}^{0}$ 6.001, de 19 de dezembro de 1973 - Estatuto do Índio. Disponível em: $<$ https://goo.gl/GifLhJ>. Acesso em: 21 out. 2016.

BUTLER, Judith. Problemas de gênero: feminismo e subversão da identidade. 1. ed. Rio de Janeiro: Civilização, 2003.

CHAMORRO, Graciela. História Kaiowa: das origens aos desafios contemporâneos. São Bernardo do Campo: Nhanduti Editora, 2015.

CUNHA, Manuela Carneiro da. Índios no Brasil: história, direitos e cidadania. São Paulo: Claro Enigma, 2012.

CUNHA, Manuela Carneiro da. O Futuro da Questão Indígena. Estudos Avançados. São Paulo, v. 8, n. 20, p. 121-136. 1994.

DELEUZE, Gilles; GUATTARI, Félix. Introdução: Rizoma. In: Mil Platôs: capitalismo e 
esquizofrenia. V. 1. São Paulo: Editora 34, 1995.

ESSELIN, Paulo Marcos; OLIVEIRA, Tito Carlos Machado de; OLIVEIRA, Marco Aurélio Machado de. Fronteiras Esquecidas: a construção de hegemonias nas fronteiras entre os rios Paraguai e Paraná. Dourados: Ed. UFGD, 2012.

FOUCAULT, Michel. Em Defesa da Sociedade. São Paulo: Martins Fontes, 2010.

FOUCAULT, Michel. Microfísica do Poder. Rio de Janeiro: Paz e Terra, 2015.

FUNDAÇÃO NACIONAL DO ÍNDIO (FUNAI). Coordenação Regional de Dourados. Processo no 08788.000038/2016-50 - Solicitação de Análise e Parecer da Procuradoria Federal Especializada Acerca dos Procedimentos Adotados para Emissão da DAP. Dourados: 2016.

FUNDAÇÃO NACIONAL DO ÍNDIO (FUNAI). Política Indigenista. 2012. Disponível em: <https://goo.gl/m1DxK2>. Acesso em: 18 nov. 2016.

FUNDAÇÃO NACIONAL DO ÍNDIO (FUNAI). Sobre a Reestruturação da Funai. 2010. Disponível em: <https://goo.gl/j37zHa>. Acesso em: 21 out. 2016.

GARFIELD, Seth. As Raízes de uma Planta que Hoje é o Brasil: os índios e o Estado-nação na Era Vargas. Revista Brasileira de História, v. 20, n. 39, São Paulo, 2000. Disponível em: $<$ https://goo.gl/LR8nBC>. Acesso em: 13 set. 2016.

GELEDÉS, Instituto da Mulher Negra. Guia de Enfrentamento ao Racismo Institucional. 2013. Disponível em: <https://goo.gl/UsJeGC>. Acesso em: 23 out. 2016.

GUARANY, Vilmar Martins Moura. Desafios e Perspectivas para a Construção e o Exercício da Cidadania Indígena. In: ARAÚJO, Ana Valéria (Org.). Povos Indígenas e a Lei dos "Brancos”: o direito à diferença. Brasília: Ministério da Educação, Secretaria de Educação Continuada, Alfabetização e Diversidade/LACED/Museu Nacional, 2006, p. 146-166.

LACERDA, Rosane. Os Povos Indígenas e a Constituinte 1987-1988. Brasília: Cimi - Conselho Indigenista Missionário, 2008.

LIMA, Antônio Carlos de Souza. O Exercício da Tutela sobre os Povos Indígenas: considerações para o entendimento das políticas indigenistas no Brasil contemporâneo. Revista de Antropologia da USP, v. 55, n. 2. São Paulo, 2012. Disponível em: <https://goo.gl/uxQg3n>. Acesso em: 3 out. 2016.

LIMA, Antônio Carlos de Souza. O Governo dos Índios Sob a Gestão do SPI. In: CUNHA, Manuela Carneiro da (Org.). História dos Índios no Brasil. São Paulo: Editora Schwarcz, 1998.

LÓPEZ, Laura Cecília. O Conceito de Racismo Institucional: aplicações no campo da saúde. Revista Interfaces, v. 16, n. 40, p. 121-134. Vale do Rio dos Sinos, 2012. Disponível em: <https://goo.gl/mUyAUc>. Acesso em: 23 out. 2016.

MACEDO, Rayane Bartolini. Debaixo da terra: uma genealogia cartográfica acerca dos discursos que permeiam as tessituras rizomáticas da PEC 215. 2017. 126 f. Dissertação (Mestrado em Sociologia) - Universidade Federal da Grande Dourados, Dourados, 2017. 
MARÉS, Carlos. As Novas Questões Jurídicas nas Relações dos Estados Nacionais com os Índios. In: LIMA, Antônio Carlos de Souza; BARROSO-HOFFMANN, Maria (Org.). Além da Tutela: bases para uma nova política indigenista III. Rio de Janeiro: LACED/Contra Capa Livraria, 2002. p. 49-61.

MEYER, Luíza Gabriela Oliveira. Rumo à descolonização? O direito de consulta e os seus (ab)usos na Reserva Indígena de Dourados (RID). 2014. 277 f. Dissertação (Mestrado em Antropologia) Universidade Federal da Grande Dourados, Dourados, 2014.

RAMOS, Adriana. Os Índios e o Novo Congresso Nacional. In: LIMA, Antônio Carlos de Souza; BARROSO-HOFFMANN, Maria (Org.). Além da Tutela: bases para uma nova política indigenista III. Rio de Janeiro: LACED/Contra Capa Livraria, 2002. p. 35-40.

RIBEIRO, Darcy. Os índios e a Civilização: A integração das populações indígenas no Brasil Moderno. São Paulo: Companhia das Letras, 1996.

SAFATLE, Wladimir. Quando as ruas queimam: manifesto pela emergência. Série PANDEMIA. São Paulo: Edições n-1, 2016.

SANT'ANA, Graziella Reis de. História, espaços, ações e símbolos das associações indígenas Terena. 2010. 331 f. Tese (Doutorado em Ciências Sociais) - Universidade Estadual de Campinas, Campinas, 2010.

SANTOS, Boaventura de Sousa. Para Além do Pensamento Abissal: das linhas globais a uma ecologia de saberes. In: SANTOS, Boaventura de Sousa; MENESES, Maria Paula (Org.). Epistemologias do Sul. São Paulo: Editora Cortez, 2010.

SCHWARCZ, Lilia M. O Espetáculo das Raças: cientistas, instituições e questão racial no Brasil (1870-1930). São Paulo: Companhia das Letras, 1993.

SUESS, Paulo. Em defesa dos povos indígenas. São Paulo: Loyola, 1980.

TYLER, Stephen. Etnografia postmoderna: desde el documento de lo oculto al oculto documento. In: MARCUS, George e CLIFFORD, James (Org.). Retóricas de la Antropologia. Barcelona: Jucar Universidad, 1991, p. 183-204.

UMBELINO, Ariovaldo. É Uma Mentira Dizer que no Brasil a Terra é Produtiva. IHU-Online, 2011. Disponível em: <https://goo.gl/by3qMr>. Acesso em: 16 out. 2016.

VIVEIROS DE CASTRO, Eduardo. Metafísicas canibais. São Paulo: N-1 edições, 2015.

VIVEIROS DE CASTRO, Eduardo. Os involuntários da Pátria. Aula Pública durante o ato “Abril Indígena”, Cinelândia, Rio de Janeiro, 20 de abril de 2016. São Paulo: n-1 edições, 2016b.

VIVEIROS DE CASTRO, Eduardo. Sobre a noção de etnocídio, com especial atenção ao caso brasileiro. 2016a. Disponível em: <https://goo.gl/6PpnpY>. Acesso em: 28 jul. 2016. 
Simone Becker

Professora associada I no curso de Direito da Faculdade de Direito e de Relações Internacionais (FADIR/UFGD). Mestre e doutora em Antropologia Social. Bolsista produtividade no CNPq.E-mail:simonebk@yahoo.com.br

Taís Cássia Peçanha Rocha Graduada em Direito pela Universidade Federal de Mato Grosso do Sul (UFMS), pósgraduanda em Direitos Humanos e Cidadania pela Universidade Federal da Grande Dourados (UFGD) e Agente em Indigenismo na Fundação Nacional do Índio, Coordenação Regional de Dourados/MS.E-mail: tais.cpr@gmail.com 


\section{ANEXO - Autorização para Acesso e Pesquisa Documental}

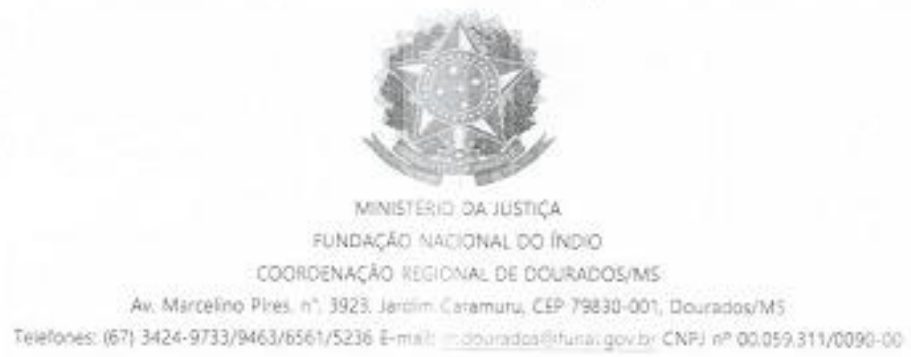

AUTORIZAÇÃO PARA ACESSO E PESQUISA DOCUMENTAL

Eu, Vander Aparecido Nishijima, na qualidade de Coordenador Regional Substituto da Coordenaçăo Regional de Dourados/MS, mediante portaria $n^{\circ} 1502 / P R E S / 2012$ de 20 de novembro de 2012, AUTORIzO a acadêmica pós graduanda TAIS DE CÁSSIA PECANHA ROCHA, a realizar consulta documental do Processo Administrativo n० $08788.000038 / 2016-50$, referente a solicitação de parecer da Procuradotia Federal Especializada e análise do procedimento de emissāo da Declaração de Aptidão ao Pronaf - DAP, bem como de todos os documentos que o guarnecem, para fins de utilização e apresentaçäo em pesquisa intitulada "(DES)INDIANIZAÇŎES E DE-VIRES (OUTROS) EM TERRAS SUL-MATO-GROSSENSES" que desenvolve como requisito para aquisição de título de Especialista, através da Universidade Federal da Grande Dourados UFGD.

Sem mais, assino o presente.

\section{Vander Aparecido Nishijima}

Coordenador Regional Subst. de Dourados

Port. No. 1502/Pres/2012, de 20/11/2012 